\title{
The Influence of Biographical Situational Factors upon Environmental Activist Behaviour: Empirical Evidence from CEE Countries
}

\author{
Audronè Telešienè, Aistè Balžekienè
}

\begin{abstract}
This study aims to provide an empirically verified exploration of factors influencing environmental activist behaviour. The authors focus on the determinants of personal environmental activist behaviour as a characteristic of the culturally specific group of Central and Eastern European (CEE) countries. A two-stage model of the biographical availability thesis is explored. Results reveal evident regional differences in patterns of public-sphere environmental behaviours across Europe. CEE countries exhibit lower levels of engagement in environmental activist behaviours than Western and Nordic European countries. The two-stage model of the biographical availability thesis is only partially confirmed. Age and employment status have a significant influence on behaviour: specifically, being 17-24 years old and in education increases availability for environmental activist behaviour. Gender has an additional influence upon participation in demonstrations and protests, with men being more participative. A low-commitment partnership status has additional influence on behavioural intentions. The results imply the need for further research into the context and cognitive determinants of environmental activist behaviour in CEE countries.
\end{abstract}

KEYWORDS Environmental behaviour, environmental activism, biographical availability, Central and Eastern European countries

\section{Introduction}

Environmental behaviour studies have increasingly been testing socio-psychological explanatory models. There is a lot of empirical support for the value-belief-norm theory (Stern 2000; Schwartz 1992), the theory of planned behaviour (Ajzen 1991; Ajzen, Albarracín and Hornik 2007), the thesis of limitative and operative determinants (Spaargaren 1997), and the thesis of constrained behaviour (e.g. Guagnano, Stern and Dietz 1995), to name a few. In analysing environmental activist behaviour, the thesis of biographical availability was introduced (McAdam 1986, 1990) and extensively tested (Beyerlein and Hipp 2006). Despite numerous empirical tests, however, there is still disagreement about how well activist behaviour might be predicted from biographical situational determinants. Some researchers have proved that

Sociálni studia. Department of Sociology FSS MU, 3/2015. S. 159-178. ISSN 1214-813X. 
biographical unavailability hinders activist behaviour (Wiltfang and McAdam 1991; Dorius and McCarthy 2011; Xiao and McCright 2014). Other groups of researchers found no significant support for the thesis (e.g. DiGrazia 2014) or only partial support (Schussman and Soule 2005; Xiao and Hong 2010). To overcome the weaknesses of the analytical model Beyerlein and Hipp (2006) introduced the two-stage model of biographical availability thesis. They state that biographical situational variables have greater influence on behavioural intentions rather than on activist behaviours themselves. They proved the two-stage model by testing their hypotheses on a nationally representative sample in the United States. However, a multicultural validation of the model is needed. The influence of biographical situational factors is universal and culturally unspecific (whereas the influence of worldview or cognitive determinants is culturally embedded). That is to say that having time constraints for activism, i.e. due to factors such as parenthood and employment status, should work universally regardless of a national context (Beyerlein and Hipp 2006). The universalist nature of the influence of biographical availability determinants highlights the importance of cross-cultural validation of this thesis. The novelty of the study presented in this article consists in looking for empirical arguments for cross-cultural validation primarily of the two-stage model of biographical availability thesis in the under-researched group of Central and Eastern European (CEE) countries.

The article employs data from the International Social Survey Programme (ISSP) Environment module, conducted in 2010 (ISSP Research Group 2012). Theoretical conceptualisation of environmental behaviour follows Stern's (2000) approach. Stern (2000) states that there are four types environmentally significant behaviour: environmental activism, nonactivist behaviours in the public sphere, private sphere environmentalism, and other environmentally significant behaviours. Other environmentally significant behaviours are defined as the behaviours conducted by individuals as organisational actors or within their work organisations. These types of environmentally significant behaviours follow different logics and have different determinants than personal environmental behaviours (Stern 2000) stemming from organisational settings, and thus are not the object of this article. Private sphere environmentalism comprises the purchase, use and disposal of personal and household products. Non-activist environmental behaviours include petitioning on environmental issues, contributing to environmental organisations, and support for or acceptance of public policies. Committed environmental activism is about membership in environmental organisations and about going on demonstrations and protests (Stern 2000: 409). Having in mind all the different types of environmental behaviour outlined above, we chose environmental activist behaviour as the object of analysis in this article.

The main aim of the article is to test the influence of biographical availability determinants on personal activist environmental behaviours and behavioural intentions in a culturally specific set of CEE countries. In order to achieve this aim we have set several tasks: testing the differences in commitment to activist environmental behaviours between two sets of countries - CEE and other Western-Nordic European countries; testing how biographical availability variables work on activist environmental behaviours and on behavioural intentions; and testing other (cognitive availability) significant predictors, i.e. knowledge and concern. 


\section{Theoretical framework: explaining environmental activist behaviour}

Environmental activist behaviour is a form of voluntary political participation (in the sense described by Verba et al. 1995) by means of which citizens communicate their environmental concerns to government officials or other stakeholders. These are collective behaviours that require commitment and that are targeted at having an indirect impact on environmental issues (Stern 2000). Keeter et al. (2002) distinguish three main categories of political participatory activities: civic activities, electoral activities and political voice activities. The personal environmental activist behaviours as measured by ISSP and analysed in this article fall under several of these categories. The environmental NGO or group membership variable falls under the 'civic' category of measures of civic engagement, and protesting behaviour falls under category of 'political voice' (see Keeter et al. 2002).

Models explaining personal environmental behaviour usually note four kinds of determinants: worldview determinants, normative determinants, exogenous factors and biographical situational factors.

Worldview determinants encompass values, attitudes, beliefs, knowledge, concern and awareness, while normative determinants encompass norms, behavioural intentions and habits. These determinants (sometimes called cognitive determinants) are included in the valuebelief-norm theory as developed by Stern's scientific group and successors (Stern et al. 1999; Stern 2000; Slimak and Dietz 2006; Thogersen 2006; de Groot and Steg 2008; Whitmarsh and O'Neill 2010).

Exogenous (or contextual) factors (explored e.g. by Stern 2000) are related to situations relatively independent from the individuals themselves, e.g. availability of infrastructure, technologies and operative determinants (Spaargaren 1997), i.e. having the necessary tools to conduct a behaviour, governmental regulations, community expectations and other societallevel factors (for social context factors see Olli, Grendstad and Wollebaek 2001) that create limiting or enabling contexts for individual behaviour.

Biographical situational factors define personal characteristics such as gender, age, income, education, parenthood, employment and marital status. These factors are not the direct causes of environmental behaviour, but rather should be understood as pre-conditions for development of a lifeworld, a worldview or a behavioural norm. Biographical situational factors should also be understood as universalist. This is because biographical constraints appear regardless of national context, but related to individual contexts.

Behavioural situational characteristics (e.g. lack of income or time) or context forces (e.g. lack of infrastructure, low community support) might produce constraints on environmental behaviour. The thesis of constrained behaviour states that behaviour that is relatively more difficult to conduct is less likely in many populations (Guagnano et al. 1995; Stern et al. 1999). Environmental activist behaviours, i.e. environmental group membership and demonstrating are definitely behaviours that require great effort in terms of time, commitment, finances and thus must be explained as highly constrained behaviours. Interestingly, Guagnano et al. (1995) state that when contextual factors are strong and environmental behaviour is constrained, e.g. difficult to conduct, time-consuming and expensive, attitudinal and normative variables only weakly correlate with behaviour. With this in mind we do not primarily seek to explain environmental activist behaviours (highly constrained behaviours) 
by attitudinal and normative determinants. Analytical models in this article will primarily focus on biographical situational determinants.

The influence of biographical situational factors upon behaviour can be briefly explained through the classical sociological notion of the everyday lifeworld, as developed by Alfred Schutz. Schutz (1973) spoke of the everyday lifeworld as a result of a sequence of biographical situations. Each individual's worldview and behaviour is different, because each individual has a unique life story, a unique set of biographical situations. Thus trying to understand these unique situations should be at the heart of sociological investigation. Biographical situations might be both enabling or constraining. Relying upon the lifeworld concept, McAdam (1986, 1990) developed his thesis of biographical availability. The thesis is mainly used to explain engagement in various social movements, but has also been applied to understanding public environmental behaviour, i.e. petition signing, protesting. Biographical availability is defined as 'the absence of personal constraints that may increase the costs and risks of movement participation' (McAdam 1986: 70). Beyerlein and Hipp produced an overview of variables used in testing the biographical availability thesis and stated that scholars have operationalised the concept of biographical availability through the variables of marital status, parenthood, employment and age (2006: 221). These characteristics of the biographical situation will be used in this article as independent variables. Additionally, gender effect will be tested. Mohai (2014: 215-216) reviewed current research on the relation between gender and environmental activism, and found that some studies found women to be less involved in environmental activism, while others show no significant correlation between gender and environmental activities. Mohai in his study (ibid.) argues that even though women are more concerned about environmental issues, they are less involved in environmental activist behaviours. In our analytical model we will also include gender as an independent variable both for environmental activist behaviours and behavioural intentions.

The biographical availability thesis has a direct connection to the constrained behaviour thesis which explains the differences between high-risk/cost and low-risk/cost behaviours (McAdam 1996). A biographical situation should be understood as a set of potentially constraining factors. Constrained behaviour is relatively more difficult to conduct. Constraints might have different origins. Some are related to the characteristics of the behaviour itself, e.g. going on a demonstration requires much greater effort than signing an e-petition while sitting at a home computer. External constraints are situated in behavioural and general social contexts. Olli et al. (2001) similarly discuss societal-level factors that make limiting or enabling contexts for individual behaviour. The availability of infrastructure and technologies would be among limitative determinants; having the necessary tools to conduct behaviour, governmental regulations, and community expectations would be among the operative determinants. Following this logic, biographical availability factors would be operative determinants of the behaviour. In some versions of the affluence thesis, availability of resources is also treated as an operative determinant. For example, Diekmann and Franzen (1999) proved that environmentalism is more prominent in wealthy countries (compared to poorer countries).

Many studies have found results that disproved the influence of biographical availability variables on environmental activist behaviours (Nepstad and Smith 1999; Passy and Giugni 2001; DiGrazia 2014). These studies have proved that constraining biographical situations 
do not hinder environmental activism. To resolve this problem the two-stage model of the thesis might be applied (developed by Beyerlein and Hipp 2006). This model explains behaviour as a two-stage process. The first stage is the development of the intention to engage in environmental behaviour. The second stage is actually conducting the activist behaviour. Thus the McAdam's biographical availability thesis must be tested both for determining the intentions of behaviour and for determining the behaviour itself. Beyerlein and Hipp (2006) proved that biographical situational factors have greater influence on behavioural intentions than on actual behaviour. Ajzen's (1991) theory of planned behaviour includes intention as an interim determinant between cognitive determinants and actual behaviour. Similarly the twostage model introduced by Beyerlein and Hipp (2006) modifies the biographical availability thesis formulated by McAdam (1986, 1990).

Using the arguments presented above, we hypothesise that biographical availability variables are significant in explaining environmental activist behaviour, but their influence is stronger on behavioural intentions than on actual reported behaviour.

\section{Data and methods}

The analysis was based on data from the ISSP module on Environment representative surveys conducted in 2010 (ISSP Research Group 2012). The ISSP Environment module is designed to measure different environmental attitudes and environmental behaviours. Eight CEE countries participated in the programme in the Environment module, 2010: Bulgaria, the Czech Republic, Croatia, Latvia, Lithuania, Russia, Slovakia and Slovenia (all countries are attributed to CEE region following OECD classification). These CEE countries compose the main set of countries for analysis in this article. In order to make a comparative analysis, an additional set of Western and Nordic European countries has been used. We selected European countries from the ISSP sample (19 countries in total - eight from CEE and 11 from Western and Nordic countries [WEO: Western European and others], based on the United Nations regional groups division (UN Department of General Assembly). The total population consists of those aged 18 and over. A stratified multi-stage random sample was applied in every country under study. Face-to-face interviews were conducted for data collection. Countries (and sample sizes) included in the analysis were: Austria $(n=1019)$, Belgium $(n=1142)$, Bulgaria $(n=1003)$, Croatia $(n=1210)$, the Czech Republic $(n=1428)$, Denmark $(n=1305)$, Finland $(n=1211)$, France $(n=2253)$, Germany $(n=1407)$, Latvia $(n=1000)$, Lithuania (n $=1023)$, Norway $(n=1382)$, Russia $(n=1619)$, Slovakia $(n=1159)$, Slovenia $(n=1082)$, Spain $(n=2560)$, Sweden $(n=1181)$, Switzerland $(n=1212)$ and the United Kingdom $(n=$ 928). The total sample of CEE and WEO countries included 25124 respondents. The total number of respondents in CEE countries was $N=9524$. Data and metadata are stored in GESIS: the Data Archive for the Social Sciences.

Two sets of dependent variables were used in this study. The first set of variables described actual reported activist behaviours. There were two variables for activist behaviour in the ISSP 2010: environmental NGO or group membership, and protesting or going on a demonstration. The question wording for environmental activist behaviours was: Are you a member of any group whose main aim is to preserve or protect the environment? (Yes/No), 
In the last five years, have you taken part in a protest or demonstration about an environmental issue? (Yes/No). The second set of dependent variables was for measuring behavioural intentions. The ISSP module on Environment included three items for measuring behavioural intentions: willingness to pay much higher taxes, willingness to pay much higher prices and willingness to cut standard of living for the sake of the environment. The question wording for behaviour intention items was: How willing would you be to pay much higher prices in order to protect the environment?, And how willing would you be to pay much higher taxes in order to protect the environment?, and And how willing would you be to accept cuts in your standard of living in order to protect the environment. A five-point Likert-type scale was used for response categories (ranging from Very willing to Very unwilling).

The three above mentioned items of behavioural intentions formed a scale with high internal consistency (Cronbach's alpha $=0.870$ ). Therefore we constructed a behavioural intention index (mean score of the three behavioural intention items at individual level), which was used for further analysis. The internal consistency of the items for environmental behaviour was not high enough (Cronbach's alpha $=0.552$ ), therefore we were not able to construct a derivative scale of public environmental behaviour. We therefore used separate behavioural items for the analysis.

One of our research questions was to analyse how the biographical situation determines environmental activism and behavioural intentions. Environmental activism items are dichotomous, so we also constructed a dichotomous variable of behavioural intentions. The level of environmental intention was divided into 'high level' and 'low level', based on the derivative environmental intentions index. If the respondent answered 'very willing' or 'fairly willing' to at least one of the three intentions items, we then labelled the level of intention as 'high'.

Biographical availability was measured through a set of five variables. A typical operational definition of biographical availability should include variables measuring marital status, parenthood, employment status and age. We also added gender. We made a modification and used the variable indicating steady partnership commitment rather than marital status. The reason for this modification was the specific context of CEE countries, having an increasing number of cohabitation instances and a decreasing numbers of marriages (Philipov 2002; Frejka 2008; Stankuniene and Maslauskaite 2008; Maslauskaite and Baublyte 2014; Mardare 2015). Another modification was related to measuring parenthood. The ISSP questionnaires do not contain direct measure of parenthood (whether a respondent has children), but rather a measure of household composition, indicating the number of pre-school and number of school-age children under seventeen. Beyerlein and Hipp (2006: 225) similarly included a measurement for the presence of children: the number of children less than 6 years old, the number of children 6 through 12 years old, and the number of children between 13 and 18 years old. Thus in our analysis, the parenthood variable was replaced by a household composition variable indicating the presence of children. In this article four variables - steady partnership, number of children in the household, employment status and age of the respondent - were used as independent variables. We use gender as an independent variable that could also determine biographical availability for environmental action. The question wording of independent variables was: Do you have a spouse or a steady partner and, if yes, do you share the same household?, How many children are there in the household: children up to school age, together with 
How many children are there in the household: children between school age and 17 years old (for the analysis we summed these two variables), Which of the following best describes your current situation? (In paid work, unemployed, in education, etc.), and the age variable was derived from the open question When were you born?

The empirical hypotheses that were tested in this paper are as follows:

(1) There are significant regional differences between Western-Nordic and CEE countries regarding public-sphere environmental behaviour patterns.

(2) Environmental behaviour and environmental intentions at the individual level in CEE countries are influenced by biographical situational determinants (thesis of biographical availability).

The analytical model followed the theoretical framework described above. For analysing the differences of commitment to environmental activist behaviours among CEE and other Western-Nordic European countries, chi-square tests were used, measuring differences between the countries for each type of environmental behaviour (the dependent variable was dichotomous). To analyse if the levels of behavioural intention (paying higher taxes, paying higher prices and cutting living costs in order to protect the environment) differ at an individual level, Friedman's test of several related samples was applied. Further we employed chisquare tests to analyse how biographical availability variables work on environmental activist behaviours and how this same set of variables works on behavioural intentions. The influence of several additional significant predictors, i.e. knowledge and concern, was tested by applying chi-square tests and Spearman's correlation analysis. Data was weighted using sample weights provided within ISSP data sets.

\section{Results}

European regional differences of public-sphere environmental behaviour

Exploration of environmental activist behaviours in CEE countries initially needs a descriptive analysis of the levels of active involvement in public-sphere environmental behaviours. The ISSP Environment module provided four items measuring public-sphere environmental behaviours: environmental group membership, protesting, petition signing, and financial support for environmental groups (the former two measure activism and the latter two measure non-activist public-sphere behaviours). All of these variables are described in this section, though only the two that indicate activism (group membership and protesting) are further employed in the explanatory analysis in the following sections. The introductory explanation also needs a comparative analysis of CEE and other European countries, thus the set of 19 European countries ( 8 of these CEE countries) has been used for analysis in this section.

Petrova and Tarrow (2007) noticed that scholars have found environmental protest potential to be weaker in Central and Eastern Europe compared with other regions because civil society in these countries emerged from a state of socialism. We compared public-sphere environmental behaviour in two European regions and the results supported these findings.

Comparing data on public-sphere environmental behaviour from 19 European countries (Table 1), we found clear regional differences between CEE and WEO countries. Individuals from Western and Nordic countries are more actively involved in all four types of public 
environmental behaviours. And in some cases regional differences are striking. $26.6 \%$ of the population in Switzerland and $29.3 \%$ of the population in France have signed a petition on environmental issues, compared with only $4.6 \%$ in Latvia and $5.1 \%$ in Russia. A strong difference between the two regions is also evident in giving financial support for environmental groups. On average $19.1 \%$ of respondents in WEO countries but only $4.9 \%$ in CEE countries say they have given money to environmental groups. The financial support for environmental groups ranges from $1.2 \%$ in Lithuania to $33.8 \%$ in Switzerland.

Activist forms of behaviour (environmental group membership and protesting) yield lowest participation rates both in WEO and CEE countries, although participation is still much higher in WEO countries $(6.7 \%$ in WEO and $2.2 \%$ in CEE for group membership; $4.6 \%$ in WEO and $3.0 \%$ in CEE for protesting). Protesting is a high-risk/cost behaviour and thus the rates are very low. Still there are some exceptional countries such as France and Spain, where approximately $10 \%$ of respondents report taking part in protests or demonstrations, compared with a European average of $4 \%$. It is interesting to note that financial contributions to environmental groups is less prominent in both France and Spain. Therefore, hypothetically, there appear to be different traditions of public environmental behaviour in different countries. For example, people in some countries tend to support environmental groups financially, but do not actively participate in protests and demonstrations personally (e.g. Switzerland), and in other countries there is a tendency to engage more actively in behaviour that does not require financial commitment (such as signing a petition or participating in a protest).

The within-region differences in CEE are also salient (Table 1). The level of petitionsigning behaviour in countries such as the Czech Republic, Slovakia or Croatia is almost at the European average. But petition-signing behaviour in Latvia, Russia and Lithuania are far below the European average measured by the ISSP 2010 Environment module.

There are several possible explanations for these clear differences in the levels of publicsphere environmental behaviours between the regions. The first is related to the state of civic society in those regions. Populations in CEE countries are quite reluctant to engage in any forms of collective action or organisational membership. Petrova and Tarrow (2007) summarized literature on citizen participation in CEE and found that the level of an individual citizen's capacity for collective action is very low. They identified several features of the societies in CEE countries that lead to radically low levels of civic participation: "weakening, demobilization, and even the disintegration of civil society; the increasing political apathy of post-socialist citizens; and radical or egoistic individualism, social anomie, amoral cynicism, paternalism" (Petrova and Tarrow 2007: 76). Similarly Letki and Mierina (2014) argue that because organised activism was outlawed under communism, CEE countries experience weak norms of formal participation in voluntary associations. This tendency of very low engagement in environmental activism in CEE countries is especially stunning when considering the fact that many of the region's independence movements in the early nineties were related to environmental issues and values. Environmental concern at that time was a driving force for collective mobilization. The shift in the focus of concern could be another explanation of these regional differences in environmental activism. This explanation is related to the significance currently attributed to environmental issues in CEE countries. Research by 
Diekmann and Franzen (1999) revealed that people in wealthy countries give priority to environmental issues much more often than people in poorer countries.

Table 1: Public-sphere environmental behaviours in Western-Nordic European and Central Eastern European countries ( $\%$ of positive answers)

\begin{tabular}{|c|c|c|c|c|c|}
\hline & $\begin{array}{l}\text { Member of } \\
\text { environmental } \\
\text { group }\end{array}$ & $\begin{array}{l}\text { Signed } \\
\text { a petition }\end{array}$ & $\begin{array}{l}\text { Given } \\
\text { money to an } \\
\text { environmental } \\
\text { group }\end{array}$ & $\begin{array}{l}\text { Taken part } \\
\text { in protest or } \\
\text { demonstration }\end{array}$ & $\begin{array}{l}\text { Average \% of } \\
\text { active people }\end{array}$ \\
\hline $\mathrm{CH}$-Switzerland & 13.5 & 26.6 & 33.8 & 4.5 & 19.6 \\
\hline FR-France & 5.8 & 29.3 & 9.4 & 10.8 & 13.8 \\
\hline AT-Austria & 7.4 & 20.7 & 20.4 & 3.5 & 13.0 \\
\hline DK-Denmark & 9.8 & 17.4 & 21.7 & 2.7 & 12.9 \\
\hline SE-Sweden & 5.4 & 19.7 & 22.6 & 2.9 & 12.7 \\
\hline GB-Great Britain & 5.7 & 22.9 & 17.0 & 2.9 & 12.1 \\
\hline DE-Germany & 5.7 & 22.4 & 15.3 & 4.3 & 11.9 \\
\hline FI-Finland & 4.9 & 14.6 & 25.9 & 1.8 & 11.8 \\
\hline NO-Norway & 4.8 & 16.3 & 22.4 & 3.3 & 11.7 \\
\hline BE-Belgium & 7.6 & 21.2 & 13.1 & 3.8 & 11.4 \\
\hline ES-Spain & 3.4 & 16.2 & 8.0 & 10.6 & 9.5 \\
\hline CZ-Czech Republic & 3.0 & 13.5 & 7.9 & 4.6 & 7.3 \\
\hline SK-Slovak Republic & 2.0 & 13.8 & 9.2 & 2.3 & 6.8 \\
\hline SI-Slovenia & 3.6 & 10.9 & 6.9 & 2.8 & 6.0 \\
\hline HR-Croatia & 2.6 & 15.7 & 4.1 & 1.9 & 6.1 \\
\hline BG-Bulgaria & 1.7 & 9.8 & 1.3 & 4.4 & 4.3 \\
\hline LV-Latvia & 1.2 & 4.6 & 5.3 & 2.6 & 3.4 \\
\hline RU-Russia & 1.7 & 5.1 & 3.2 & 3.0 & 3.2 \\
\hline LT-Lithuania & 1.8 & 6.6 & 1.2 & 2.7 & 3.1 \\
\hline Total WEO & 6.7 & 20.7 & 19.1 & 4.6 & 12.8 \\
\hline Total CEE & 2.2 & 10 & 4.9 & 3.0 & 5.0 \\
\hline $\begin{array}{l}\text { Total European } \\
\text { countries (mean } \\
\text { at country level) }\end{array}$ & 4.8 & 16.2 & 13.1 & 4.0 & 9.7 \\
\hline
\end{tabular}

Note: Differences between countries are statistically significant, chi-square test $p=0.00$ for all four items of environmental behaviour in grey - CEE countries.

Source: ISSP - Environment, 2010, Total (European countries), $N=25124$

The ISSP Environment survey had a question about the most important issues for the country today. There were various answers including the environment and the economy. Figure 1 presents a comparison of the rates of those who selected 'the environment' and those 
who selected 'the economy' as the most important issue for their country. The figure also shows the level of engagement in environmental activist behaviour. The tendency is quite clear that people in CEE countries are more concerned with the economic situation. In their opinion, environmental issues are among the least important. It should also be noted that countries with the highest level of engagement in public environmental behaviours also have the highest rates of those who indicated environmental problems as being the most important. However, environmental issues outweigh concerns about the economic situation in only two countries (Norway and Switzerland).

Figure 1: The country level distribution of environmental activism compared with those indicating environment and economy as the most important issue for their country (\%)

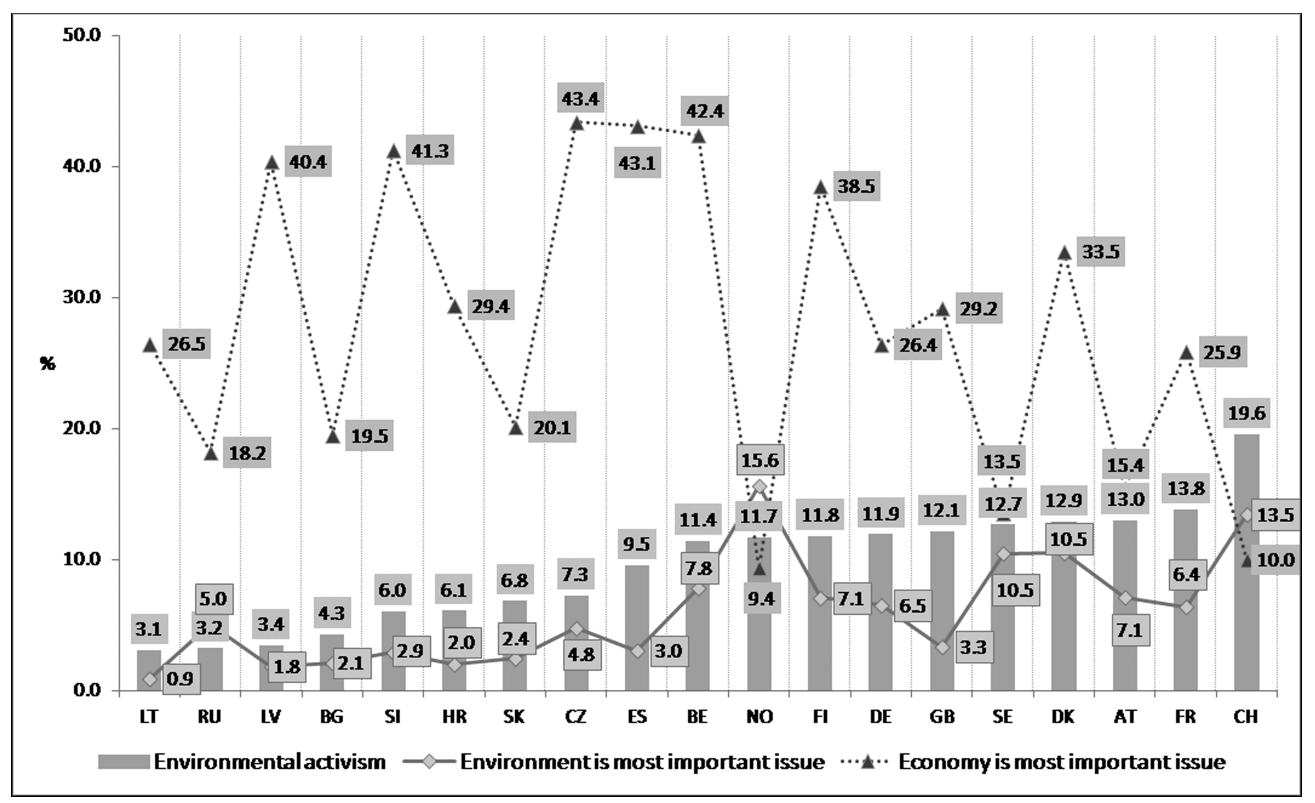

Source: ISSP - Environment, 2010, Total (European countries), $N=25124$

After analysing the differences and specific characteristics of environmental publicsphere behaviour in CEE and WEO regions, we further turned to the main questions of the article: Can environmental activist behaviours in CEE region be explained through the biographical availability thesis? Before testing the model we explored the relation between behavioural intentions and activist behaviour. 
The relation of behavioural intentions to environmental activist behaviours

The focus of this article is environmental activism, which is defined by Stern (2000) as membership in environmental organisations and protesting. Following the two-stage model for explaining environmental activist behaviours, we turned to the analysis of actual behaviour trends and an analysis of behavioural intentions. We hypothesised that behavioural intentions are a good prognostic tool for explaining future behavioural patterns. The data of behavioural intentions in CEE countries is presented in Table 2.

Table 2: Intentions of environmental behaviour in CEE countries*

\begin{tabular}{|l|c|c|c|c|}
\hline & \multicolumn{2}{|c|}{ Willingness to make trade-offs for environment: ** } & $\begin{array}{c}\text { Average \% } \\
\text { of behavioural } \\
\text { intentions }\end{array}$ \\
\cline { 2 - 5 } & Pay higher prices & Pay higher taxes & $\begin{array}{c}\text { Cut standard of } \\
\text { living }\end{array}$ & 23.1 \\
\hline SI-Slovenia & 28.3 & 17.6 & 24.3 & $\mathbf{2 6 . 3}$ \\
\hline SK-Slovak Republic & 18.8 & 13.7 & 23.2 & 18.9 \\
\hline RU-Russia & 18.0 & 13.9 & 14.7 & 18.4 \\
\hline CZ-Czech Republic & 16.6 & 12.1 & 14.6 & 14.4 \\
\hline HR-Croatia & 11.8 & 9.5 & 13.8 & 11.9 \\
\hline BG-Bulgaria & 26.2 & 19.5 & 9.5 & 19.8 \\
\hline LT-Lithuania & 13.0 & 12.3 & 6.7 & 11.6 \\
\hline LV-Latvia & 10.5 & 8.1 & 17.9 & $\mathbf{8 . 4}$ \\
\hline Total CEE & 17.8 & 13.3 & & 16.3 \\
\hline
\end{tabular}

Source: ISSP - Environment, 2010, Total (CEE) $N=9524$

* Table presents cumulative percentages of responses "very willing" and "fairly willing"

** At the individual level of CEE countries, the differences among three types of behavioural intentions are significant: Friedman's test of several related samples, $p=0.000$.

Compared to the level of public environmental activism discussed above, environmental behavioural intentions are higher than actual environmental behaviour in CEE countries.

Bamberg and Moser (2007) analysed psychosocial determinants of pro-environmental behaviours and found that behavioural intentions have a mediating role in this relationship. In their study (Bamberg and Moser 2007), behavioural intentions explained $27 \%$ of selfreported pro-environmental behaviour. We looked into behavioural intentions related to environmental activism.

Our results revealed a significant association between the forms of environmental activism and the intentions of environmental behaviour. Those with higher levels of environmental behavioural intentions were more often members of environmental groups and took part in protests and demonstrations. 
Table 3: The level of environmental activism among people with low and high behavioural intentions at the individual level (\%)

\begin{tabular}{|l|c|c|c|c|}
\hline & \multicolumn{2}{|c|}{$\begin{array}{c}\text { Member of a group to protect } \\
\text { environment }\end{array}$} & \multicolumn{2}{c|}{$\begin{array}{c}\text { Taken part in a protest or } \\
\text { demonstration about an } \\
\text { environmental issue }\end{array}$} \\
\cline { 2 - 5 } & Yes & No & Yes & No \\
\hline High level of intentions & 5.6 & 94.4 & 5.8 & 94.2 \\
\hline Low level of intentions & 1.4 & 98.6 & 2.5 & 97.5 \\
\hline Total & 2.2 & 97.8 & 3.1 & 96.9 \\
\hline & \multicolumn{2}{|c|}{ Chi-square, sig. 0.00} & \multicolumn{2}{c|}{ Chi-square, sig. 0.00} \\
\hline
\end{tabular}

Source: ISSP - Environment, 2010, Total (CEE) $N=9524$

The relation between biographical availability items and environmental activist behaviours and intentions

Following the two-stage model of the biographical availability thesis, as introduced by Beyerlein and Hipp (2006), in this section we test the influence of biographical situational factors on behavioural intentions and actual environmental activist behaviour.

The biographical availability thesis would suggest the significant influence of age, parenthood, employment status and partnership status on group membership and protesting behaviours. Gender is also an important biographic factor. As found by many scholars (e.g. Schussman and Soule 2005; Xiao and Hong 2010), these relations are, more often than not, rather weak or only some of the biographical situation variables are significantly related to behaviour. To explore the relations between biographical situational factors and actual activist behaviour, it would have been valuable to develop regression models. Activist behaviours of group membership and protesting are dichotomous variables. But the proportion of those answering 'Yes' is much larger than those answering 'No', and this extremely unequal distribution hinders the meaning of regression models (Cekanavicius and Murauskas 2002). Thus we used chi-square to test if environmental activism behaviours and behavioural intentions differed significantly within the categories of biographical situational variables (see Tables 4 and 5).

Only two out of five biographical situational variables were found to be significantly related to environmental group membership (as an environmental activist behaviour) in CEE countries: age and main status (Table 4). Taking part in protests or demonstrations (as an activist environmental behaviour) is significantly related to age, main status and gender.

Three biographical situational variables - age, main status and partnership commitment - have a significant relation with behavioural intentions (Table 5). Age has an effect on both environmental group membership and protesting, and on behavioural intentions, where 17-24 year-old respondents were more involved than older respondents. This is somehow in accordance with another independent variable that significantly influences activist behaviours and behavioural intentions - main status. Those still in education are more willing to contribute and participate than the rest (regardless of whether they are employed, unemployed, 
retired, etc.). Behavioural intentions, contrary to the actual reported activist behaviour, have a significant relation to partnership status. Those who have a partner but do not live in the same household (low-commitment partnership) tend to participate more in environmental activist behaviours.

Table 4: Environmental activist behaviour patterns by biographical situation variables (\%)

\begin{tabular}{|c|c|c|c|c|c|c|}
\hline & \multicolumn{3}{|c|}{$\begin{array}{c}\text { Member of a group to protect } \\
\text { environment }\end{array}$} & \multicolumn{3}{|c|}{$\begin{array}{l}\text { Taken part in a protest or } \\
\text { demonstration about an } \\
\text { environmental issue }\end{array}$} \\
\hline & Yes & No & $\begin{array}{c}\text { Chi-square } \\
\text { test, sig. }\end{array}$ & Yes & No & $\begin{array}{c}\text { Chi-square } \\
\text { test, sig. }\end{array}$ \\
\hline Total, CEE & $2.2 \%$ & $97.8 \%$ & & $3.1 \%$ & $96.9 \%$ & \\
\hline $\begin{array}{l}\text { Gender } \\
\text { Male } \\
\text { Female }\end{array}$ & $\begin{array}{l}2.4 \\
2.1\end{array}$ & $\begin{array}{l}97.6 \\
97.9 \\
\end{array}$ & .233 & $\begin{array}{l}3.6 \\
2.6\end{array}$ & $\begin{array}{l}96.4 \\
97.4 \\
\end{array}$ & $.008^{*}$ \\
\hline $\begin{array}{l}\text { Partnership } \\
\text { Yes, have partner; live in same } \\
\text { household } \\
\text { Yes, have partner; don't live } \\
\text { in same household } \\
\text { No partner }\end{array}$ & $\begin{array}{l}2.1 \\
3.1 \\
2.3\end{array}$ & $\begin{array}{l}97.9 \\
96.9 \\
97.7\end{array}$ & .426 & $\begin{array}{l}2.9 \\
4.8 \\
3.3\end{array}$ & $\begin{array}{l}97.1 \\
95.2 \\
96.7\end{array}$ & .091 \\
\hline $\begin{array}{l}\text { Age } \\
\qquad \begin{array}{l}17-24 \\
25-39 \\
40-54 \\
55+\end{array}\end{array}$ & $\begin{array}{l}3.3 \\
2.1 \\
2.3 \\
1.8 \\
\end{array}$ & $\begin{array}{l}96.7 \\
97.9 \\
97.7 \\
98.2 \\
\end{array}$ & $.023^{* *}$ & $\begin{array}{l}4.6 \\
2.8 \\
3.0 \\
2.7 \\
\end{array}$ & $\begin{array}{l}95.4 \\
97.2 \\
97.0 \\
97.3\end{array}$ & $.006^{*}$ \\
\hline $\begin{array}{l}\text { Children in household } \\
\text { None } \\
1 \\
2 \\
3 \text { or more }\end{array}$ & $\begin{array}{l}2.5 \\
2.0 \\
1.4 \\
3.3\end{array}$ & $\begin{array}{l}97.5 \\
98.0 \\
98.6 \\
96.7\end{array}$ & .147 & $\begin{array}{l}3.4 \\
2.7 \\
1.9 \\
4.2\end{array}$ & $\begin{array}{l}96.6 \\
97.3 \\
98.1 \\
95.8\end{array}$ & .078 \\
\hline $\begin{array}{l}\text { Main employment status }{ }^{a} \\
\text { In paid work } \\
\text { Unemployed and looking } \\
\text { for a job } \\
\text { In education } \\
\text { Permanently sick or disabled } \\
\text { Retired } \\
\text { Domestic work }\end{array}$ & $\begin{array}{l}2.5 \\
1.4 \\
4.6 \\
1.8 \\
1.6 \\
0.9\end{array}$ & $\begin{array}{l}97.5 \\
98.6 \\
95.4 \\
98.2 \\
98.4 \\
99.1\end{array}$ & $.000^{*}$ & $\begin{array}{l}3.2 \\
3.1 \\
6.6 \\
2.3 \\
2.0 \\
0.6\end{array}$ & $\begin{array}{l}96.8 \\
96.9 \\
93.4 \\
97.7 \\
98.0 \\
99.4\end{array}$ & $.000^{*}$ \\
\hline
\end{tabular}

Source: ISSP - Environment, 2010, Total (CEE) $N=9524$

a Category "Apprentice or trainee" was removed from analysis because of the small $n$

* Significant at 0.01

** Significant at 0.05

The results are ambiguous. The mechanism of how age influences activist behaviours in many countries is related to a cohort effect, referring to widespread social movements in the 1960s or 1970s, especially in the US (e.g. McAdam 1986, 1990). But in CEE countries this explanation has not yet been tested, because in the 1960s and 1970s these countries were under communist regimes, and experienced the upheaval of social movements in 
the 1980s and 1990s. Data show that those aged 40-54 (who were young in the 1980s or 1990s) slightly more often tend to be members of environmental groups than respondents from other age cohorts. But the number of cases is too low, thus such results will have to be statistically tested in future research. The most active age group, 17-24 year olds, has undergone their socialisation after the fall of soviet regimes. The cohort effect again will have to be tested in future research.

Table 5: The level of behavioural intentions by biographical situation variables

\begin{tabular}{|l|c|c|c|}
\hline & \multicolumn{3}{|c|}{ Level of intentions to engage in environmentally } \\
& \multicolumn{2}{|c|}{ friendly behaviours } \\
\hline & $\begin{array}{c}\text { High level of } \\
\text { intentions }\end{array}$ & $\begin{array}{c}\text { Low level of } \\
\text { intentions }\end{array}$ & $\begin{array}{c}\text { Chi-square test, } \\
\text { sig. }\end{array}$ \\
\hline Total, CEE & $18 \%$ & $81.4 \%$ & \\
\hline $\begin{array}{l}\text { Gender } \\
\text { Male }\end{array}$ & $18.9 \%$ & $81.1 \%$ & .390 \\
Female & $18.2 \%$ & $81.8 \%$ & \\
\hline Partnership & & & \\
Yes, have partner; live in same household & $19.3 \%$ & $80.7 \%$ & $.004^{*}$ \\
Yes, have partner; don't live in same household & $22.6 \%$ & $77.4 \%$ & \\
No partner & $17.1 \%$ & $82.9 \%$ & \\
\hline Age & & & $.00^{*}$ \\
17-24 & $22.2 \%$ & $77.8 \%$ & \\
$25-39$ & $20.6 \%$ & $79.4 \%$ & \\
40-54 & $18.6 \%$ & $81.4 \%$ & \\
55+ & $15.4 \%$ & $84.6 \%$ & .128 \\
\hline Children in household & & & \\
None & $17.7 \%$ & $82.3 \%$ & \\
I & $20.5 \%$ & $79.5 \%$ & \\
2 & $18.7 \%$ & $81.3 \%$ & \\
3 or more & $18.8 \%$ & $81.3 \%$ & \\
\hline Main employment status ${ }^{a}$ & & & \\
In paid work & $20.6 \%$ & $79.4 \%$ & \\
Unemployed and looking for a job & $13.1 \%$ & $86.9 \%$ & \\
In education & $27.1 \%$ & $72.9 \%$ & \\
Permanently sick or disabled & $11.0 \%$ & $89.0 \%$ & \\
Retired & $14.6 \%$ & $85.4 \%$ & \\
Domestic work & $17.4 \%$ & $82.6 \%$ & \\
\hline
\end{tabular}

${ }^{\text {a }}$ Category "Apprentice or trainee" was removed from analysis because of the small $n$

Note: If respondent answered "very willing to fairly willing" to at least one of three questions related to behavioural intentions, they were attributed to the group "high level of intentions".

* Significant at 0.01

The effect of main status on the environmental activist behaviour items is interpretable through the thesis of biographical availability. These are the respondents who are rather unconstrained by partnership and parenthood commitments, living in educational environments that more often than not encourage active involvement in various forms of collective action. Many schools have environmental clubs or have green school initiatives, students 
might have internships in environmental NGOs and this might raise the number of those saying 'Yes, I have been member of environmental group recently'.

Gender differences are only significant regarding taking part in demonstrations or protests. Men are slightly more likely to engage in this kind of behaviour. However at the level of behavioural intention, there are no significant differences between genders. Our results are partially in line with the Mohai (2014) study which showed women to be more concerned with environmental issues than men, but less likely to be engaged in environmental activism.

Generally, being young and being in education have to be considered as important prerequisites for environmental activist behaviours in CEE countries. Thus we can discuss biographical availability, but cannot say anything statistically significant about biographical unavailability, as any other status leads to non-participation. Our findings from CEE countries do not support Beyerlein and Hipp's (2006) conclusion that biographical unavailability does not hinder participation in environmental activism.

Having no robust proof for the biographical availability thesis we turn to an analysis of the influence of cognitive determinants.

\section{Influence of cognitive determinants upon environmental activism}

Corrigall-Brown (2011) states that ideological factors are important for engagement in protest and social movements. An analysis by Dorius and McCarthy (2011) also indicates that worldview and normative factors are better predictors of environmental activist behaviours than biographical availability predictors. This does not neglect the importance of biographical availability determinants, but rather prioritises cognitive determinants over biographical availability determinants. Corrigall-Brown (2011) argues that the prime determinants are the cognitive ones, but these are not sufficient to cause environmental activism. She admits the significance of biographic availability as a prerequisite for engaging in contentious political action and sustaining such action over time. As many findings show, knowledge and concern are the two most important cognitive predictors. Thus, further on in this article we test the relation of these two determinants to environmental activist behaviours.

The level of environmental concern (question wording Generally speaking, how concerned are you about environmental issues?) is significantly different for those who are members of environmental groups $(M=4.15)$ and those who are not members $(M=3.38)$ (Mann-Whitney U test, sig. $=0.00$ ). Environmental concern was measured on a five-point Likert-type scale (where 1 is "not at all concerned" and 5 is "very concerned"). The same is true for the second type of environmental activism. The mean score of environmental concern among those who took part in protests or demonstrations is higher $(M=4.04)$ than among those who did not take part $(M=3.37)$ (Mann-Whitney $\mathrm{U}$ test, sig. $=0.00)$. Among analysed CEE countries, the highest level of environmental concern was in Slovenia $(M=4.07)$, and the lowest in the Czech Republic $(M=2.88)$.

Knowledge is another classical determinant used for explaining environmental behaviours. The ISSP 2010 measured subjective knowledge, asking if people know about the causes and solutions to environmental problems. The data revealed that in CEE countries people know more about the causes of environmental problems (mean score 2.95 from 
the five-point Likert scale) than about the solutions to these problems (mean score 2.65) (Wilcoxon test, sig. $=0.00$ ). In general, $27.1 \%$ of respondents from CEE countries indicated that they know almost nothing or know nothing at all about the solutions to environmental problems. There is a significant correlation between subjective knowledge of environmental degradation causes and the behavioural intentions index (Spearman's $r h o=-0.235, p=0.00$ ) and between knowledge of solutions and the behavioural intentions index (Spearman's rho $=$ $-0.240, p=0.00)$.

Thus it appeared that cognitive factors are significant and might provide a much better explanation for environmental activism patterns in CEE than biographical situation variables. For example, from those who answered 'know a great deal' about the solutions to environmental problems, $12 \%$ are members of an environmental group (in comparison to $2.3 \%$ of the total sample) and $11.7 \%$ participated in protests or demonstrations to protect the environment (in the total sample it is $3.1 \%$ ). On the other hand, the direction of this relationship is not straightforward. Those who are members of environmental groups possibly evaluate their knowledge about the causes and solutions to environmental problems much higher than the others.

\section{Conclusions and discussion}

Study results reveal stunning regional differences across Europe in terms of public-sphere environmental activist behaviour patterns. Central and Eastern European countries clearly differ from the countries in Western and Nordic Europe. Environmental group membership, protesting, petition signing and giving financial support to environmental groups are far less pronounced in CEE countries. Results reveal that activist type environmental behaviour environmental group membership and protesting - is least pronounced of all public-sphere environmental behaviours in European countries. Only a small percentage of the population across all CEE countries are engaged in these activities, compared with much higher levels in WEO countries. The findings correspond to results obtained by Petrova and Tarrow (2007), who state that citizens' capacity for collective action is generally very low in CEE countries. The other significant factor, apart from the lack of incentives for collective action, is the significance attributed to environmental issues by CEE populations. Environmental issues are currently considered by CEE populations as less important for their countries than are socioeconomic issues.

Data on environmental activist behaviour in CEE countries partially confirms the biographical availability thesis. Biographical situational determinants (age and main status) have a significant influence on environmental activist behaviours both directly and through the normative determinant of environmental behavioural intentions (behavioural intentions are significantly associated with levels of engagement in environmental activism). Those who are young and still in education are more involved in environmental activist behaviours. Additionally, gender is significantly related to participation in protests or demonstrations on environmental issues (men being more participative). We would, however, prefer to discuss biographical situational factors not as constraining factors, but as enabling factors. Being in education and being 17-24 years old in CEE should be treated as enabling factors to take on 
environmental activist behaviours. Any other status definitely leads to non-participation. The CEE data analysis does not provide a firm validation of the two-stage model of biographical availability thesis as developed by Beyerlein and Hipp (2006). It also dismisses the idea of the universalist nature of the mechanisms of influence of biographical situational factors.

The data clearly show that it is not the biographical situational factors that provide the solid explanatory power for low environmental activist behaviours in CEE countries. This is not to neglect the importance of biographical availability determinants, but rather to prioritise the cognitive determinants and national context over biographical availability determinants. Our findings indicate that there is a need for other explanatory models. Hypothetically the national or regional context plays an important role (supports the analytical framework by e.g. Olli et al. 2001). The affluence thesis, usually used for explaining environmental concern and levels of behavioural intentions, might possibly work in explaining activist behaviours. It might be that biographic unavailability hinders activist behaviour only under stable socioeconomic conditions. Our results would also suggest the power of cognitive determinants. This is in line with the findings of Dorius and McCarthy (2011) who indicate that worldview and normative factors are better predictors of environmental activist behaviours than biographical availability predictors. We similarly find significant relations between environmental concern, environmental knowledge and environmental activist behaviours.

In sum, there are evident regional differences in patterns of public-sphere environmental behaviour across Europe. The two-stage model of biographical availability thesis is only partially confirmed by CEE data. The results imply the need for further research into context and cognitive determinants for environmental activist behaviours in CEE countries. The findings are significant in that they contribute to a better understanding of cross-cultural differences in environmental activist behaviours.

\section{Acknowledgements}

The article has been prepared as a result of several research projects. Data collection and documentation, as well as primary analysis was completed for the research project 'Monitoring of social problems: implementation of the International Social Survey Programme (ISSP)'. The research was funded by a grant (No. SIN-15/2010) from the Research Council of Lithuania. The period of implementation 2010-2011, was coordinated by Kaunas University of Technology, Institute of Politics and Public Administration. Analysis was completed and the article prepared under the research project 'International social survey programme: citizenship, work orientations and social welfare in Lithuania (ISSP LT-CIWO)', funded by a grant (No. MIP-082/2014) from the Research Council of Lithuania. The period of implementation 2014-2016, was coordinated by Kaunas University of Technology, Institute of Public Policy and Administration. 


\section{References}

AJZEN, Icek. 1991. "The Theory of Planned Behavior." Organizational Behavior and Human Decision Processes 50(2): 179-211.

AJZEN, Icek, Dolores ALBARRACÍN and Robert HORNIK (eds.). 2007. Prediction and Change of Health Behavior: Applying the Reasoned Action Approach. Mahwah: Psychology Press.

BAMBERG, Sebastian and Guido MÖSER. "Twenty Years after Hines, Hungerford, and Tomera. A New Meta-Analysis of Psycho-Social Determinants of Pro-Environmental Behaviour." Journal of Environmental Psychology 27(1): 14-25.

BEYERLEIN, Kraig and John R. HIPP. 2006. "A Two-Stage Model for a Two-Stage Process: How Biographical Availability Matters for Social Movement Mobilization.” Mobilization: An International Quarterly 11(3): 299-320.

ČEKANAVIČIUS, Vydas and Gediminas MURAUSKAS. 2002. Statistika II ir jos taikymai. Vilnius: TEV.

CORRIGALL-BROWN, Catherine. 2011. Patterns of Protest: Trajectories of Participation in Social Movements. Stanford: Stanford University Press.

DE GROOT, Judith I. M. and Linda STEG. 2008. "Value Orientations to Explain Beliefs Related to Environmental Significant Behavior: How to Measure Egoistic, Altruistic, and Biospheric Value Orientations." Environment and Behavior 40(3): 330-354.

DIEKMANN, Andreas and Axel FRANZEN. 1999. "The Wealth of Nations and Environmental Concern." Environment and Behavior 31(4): 540-549.

DIGRAZIA, Joseph. 2014. "Individual Protest Participation in the United States: Conventional and Unconventional Activism.” Social Science Quarterly 95(1): 111-131.

DORIUS, Cassandra R. and John D. McCARTHY. 2011. "Understanding Activist Leadership Effort in the Movement Opposing Drinking and Driving." Social Forces 90(2): 453-473.

FREJKA, Tomas. 2008. "Overview Chapter 5: Determinants of Family Formation and Childbearing during the Societal Transition in Central and Eastern Europe.” Demographic Research 19(7): 139-170.

GUAGNANO, Gregory A., Paul C. STERN and Thomas DIETZ. 1995. "Influences on Attitude-Behavior Relationships a Natural Experiment with Curbside Recycling." Environment and Behavior 27(5): 699-718.

ISSP RESEARCH GROUP. 2012. International Social Survey Programme: Environment III - ISSP 2010. Cologne: GESIS Data Archive. ZA5500 Data file Version 2.0.0. Retrieved December 28, 2014 (http://zacat.gesis.org/webview/).

KEETER, Scott, Cliff ZUKIN, Molly ANDOLINA and Krista JENKINS. 2002. "The Civic and Political Health of the Nation: A Generational Portrait." Center for Information and Research on Civic Learning and Engagement (CIRCLE). Retrieved December 28, 2014 (http://www.civicyouth.org/ research/products/Civic_Political_Health.pdf).

LETKI, Natalia and Inta MIERIN̦A. 2014. "Inequality and Social Capital in Post-Communist Europe." Pp. 147-168 in Social Capital and Economics: Social Values, Power, and Social Identity, edited by Asimina CHRISTOFOROU and John B. DAVIS. London: Routledge.

MARDARE, Raluca, 2015. "Romanian Family Between Traditions and Modernism." Cross Cultural Management Journal 7: 21-29.

MASLAUSKAITĖ, Aušra and Mare BAUBLYTE். 2014. "Education and Transition from Cohabitation to Marriage in Lithuania." The History of the Family: 1-16.

McADAM, Doug. 1986. "Recruitment to High-Risk Activism: The Case of Freedom Summer." American Journal of Sociology 92(1): 64-90.

McADAM, Doug. 1990. Freedom Summer. New York: Oxford University Press. 
MOHAI, Paul. 2014. "Men, Women and the Environment: An Examination of the Gender Gap in Environmental Concern and Activism." Pp. 215-240 in Women Working in the Environment: Resourceful Natures, edited by Carolyn E. SACHS. New York: Taylor and Francis.

NEPSTAD, Sharon E. and Christian SMITH. 1999. "Rethinking Recruitment to High-Risk/Cost Activism: The Case of Nicaragua Exchange." Mobilization: An International Quarterly 4(1): 25-40.

OECD. Glossary of Statistical Terms. Retrieved December 28, 2014 (http://stats.oecd.org/glossary/detail. asp? ID $=303$ ).

OLLI, Eero, Gunnar GRENDSTAD and Dag WOLLEBAEK. 2001. "Correlates of Environmental Behaviors Bringing Back Social Context.” Environment and Behavior 33(2): 181-208.

PASSY, Florence and Marco GIUGNI. 2001. "Social Networks and Individual Perceptions: Explaining Differential Participation in Social Movements.” Sociological Forum 16(1): 123-153.

PETROVA, Tsveta and Sidney TARROW. 2007. "Transactional and Participatory Activism in the Emerging European Polity the Puzzle of East-Central Europe." Comparative Political Studies 40(1): 74-94.

PHILIPOV, Dimiter. 2002. "Fertility in Times of Discontinuous Societal Change: The Case of Central and Eastern Europe." MPIDR Working Paper WP 2002-024. Rostock: Max Planck Institute for Demographic Research.

SCHUSSMAN, Alan and Sarah A. SOULE. 2005. "Process and Protest: Accounting for Individual Protest Participation.” Social Forces 84(2): 1083-1108.

SCHUTZ, Alfred. 1973. The Structures of the Life-World. New York: Northwestern University Press.

SCHWARTZ, Shalom H. 1992. "Universals in the Content and Structure of Values: Theoretical Advances and Empirical Tests in 20 Countries." Advances in Experimental Social Psychology 25(1): 1-65.

SLIMAK, Michael W. and Thomas DIETZ. 2006. "Personal Values, Beliefs, and Ecological Risk Perception." Risk Analysis 26(6): 1689-1705.

SPAARGAREN, Gert. 1997. The Ecological Modernization of Production and Consumption (Essays in Environmental Sociology). Wageningen: Landbouwuniversiteit Wageningen.

STANKUNIENE, Vlada and Ausra MASLAUSKAITE. 2008. "Family Transformations in the PostCommunist Countries: Attitudes Toward Changes." Pp. 113-138 in People, Population Change and Policies: Lessons from the Population Policy Acceptance Study Vol. 1: Family Change, edited by Charlotte HÖHN, Dragana AVRAMOV and Irena E. KOTOWSKA. The Hague: Springer Netherlands.

STERN, Paul C. 2000. "New Environmental Theories: Toward a Coherent Theory of Environmentally Significant Behavior.” Journal of Social Issues 56(3): 407-424.

STERN, Paul C., Thomas DIETZ, Troy D. ABEL, Gregory A. GUAGNANO and Linda KALOF. 1999. "A Value-Belief-Norm Theory of Support for Social Movements: The Case of Environmentalism." Human Ecology Review 6(2): 81-98.

THØGERSEN, John. 2006. "Norms for Environmentally Responsible Behaviour: An Extended Taxonomy." Journal of Environmental Psychology 26(4): 247-261.

UNITED NATIONS GENERAL ASSEMBLY AND CONFERENCE MANAGEMENT. 2014. "United Nations Regional Groups of Member States.” Retrieved December 28, 2014 (http://www.un.org/ depts/DGACM/RegionalGroups.shtml).

VERBA, Sidney, Kay L. SCHLOZMAN and Henry E. BRADY. 1995. Voice and Equality: Civic Voluntarism in American Politics. Cambridge, MA: Harvard University Press.

WHITMARSH, Lorraine and Saffron O'NEILL. 2010. "Green Identity, Green Living? The Role of Pro-Environmental Self-Identity in Determining Consistency Across Diverse Pro-Environmental Behaviours." Journal of Environmental Psychology 30(3): 305-314.

WILTFANG, Gregory L. and Doug McADAM. 1991. "The Costs and Risks of Social Activism: A Study of Sanctuary Movement Activism.” Social Forces 69(4): 987-1010. 
XIAO, Chenyang and Hong DAYONG. 2010. "Gender Differences in Environmental Behaviors in China." Population and Environment 32(1): 88-104.

XIAO, Chenyang, and Aaron M. McCRIGHT. 2014. "A Test of the Biographical Availability Argument for Gender Differences in Environmental Behaviors." Environment and Behavior 46(2): 241-263.

\section{Authors}

Audroné Telešiene is associate professor and senior researcher in sociology at the Institute of Public Policy and Administration, Kaunas University of Technology. Her research interests include sustainability issues, climate change, environmental sociology and social research methodology.

Contact: audrone.telesiene@ktu.lt

Aisté Balžekiene is associate professor and senior researcher in sociology at the Institute of Public Policy and Administration, Kaunas University of Technology. Her research interests are: sociology of science and technology, environmental sociology, urban studies, social perception of environmental and technological risks, social research methodology.

Contact: aiste.balzekiene@ktu.lt 